\title{
OLHA HONCHARENKO*
}

\section{OLEKSANDR KULCZYCKI'S PHILOSOPHY AND THE LVIV-WARSAW SCHOOL}

Słowa kluczowe: filozofia, Aleksander Kulczycki, Kazimierz Twardowski, Szkoła Lwowsko-Warszawska

Keywords: philosophy, Oleksandr Kulczycki, Kazimierz Twardowski, Lviv-Warsaw School

* Olha Honcharenko - Doctor of Philosophy, Associate Professor at the Pedagogic and Social-Economic Disciplines Department of the National Academy of State Border Service of Ukraine named after Bohdan Khmelnytskyi (Ukraine); board member at Kazimierz Twardowski Philosophical Society of Lviv; author of the monograph Philosophy of Education at the Lviv-Warsaw School (2018), translator from Polish together (with Markian Bondarchuk, Ihor Karivets and Stepan Ivanyk) of the book Kazimierz Twardowski. Selected works (2018). Research interests: philosophy of education, the Lviv-Warsaw School.

Address for correspondence: National Academy of State Border Service of Ukraine named after Bohdan Khmelnytskyi, the Pedagogic and Social-Economic Disciplines Department, Shevchenko str. 46, 29007 Khmelnytskyi, Ukraine. E-mail: olgegoncharenko@gmail.com. 


\section{Introduction}

Oleksandr Kulczycki (1895-1980) - the Ukrainian philosopher, psychologist, teacher, public cultural and educational figure. ${ }^{1}$ According to the opinion established in the Ukrainian philosophy, the main source of Oleksandr Kulczycki's philosophical views was philosophy of Immanuel Kant in which Kulczycki allegedly found "two basic principles of philosophical reasoning: critical rationalism and an anthropological approach to all issues of philosophy" (Mytrovych, 1985, p. 7).

The study of Oleksandr Kulczycki's scientific work by the Ukrainian philosopher Stepan Ivanyk disproved this idea. Ivanyk demonstrated Kulczycki's affiliation to the Lviv-Warsaw School (hereinafter referred to as LWS) as a multicultural intellectual formation with its Ukrainian branch as an integral part. ${ }^{2}$ The reason for this was the correspondence of Oleksandr Kulczycki's works with Jan Wolenski's (1985, pp. 9-10) definition of "the Lviv-Warsaw School" and the definitions of "the Lviv-Warsaw School" and "the student of Twardowski" by Stefan Zamecki (1977, pp. 34-35; Ivanyk, 2014, pp. 29-30).

Stepan Ivanyk has found out that Oleksandr Kulczycki studied philosophy under the founder of the LWS, Kazimierz Twardowski. Kulczycki's written answers of 1913, that were found in the Twardowski's archive at the University of Warsaw, became the proof of that (Ivanyk, 2014, p. 55). Ivanyk has also reviled that Kulczycki participated at the meetings of Polish Philosophical Society (hereinafter referred to as PPS). The evidence of this were the reports from the scientific meetings of PPS, published between 1904-1911 in the Warsaw "Philosophical Movement", and since 1911 in the Lviv "Philosophical Movement" (Ivanyk, 2014, p. 48). ${ }^{3}$ In addition, Stepan Ivanyk took into account the fact that in 1936 Oleksandr Kulczycki, at the

1 The biography and bibliography of the Ukrainian scholar can be found in: Yerzhabkova (1981), Ivanyk (2014).

2 F. Brentano's influence on Ukrainian philosophy through K. Twardowski. S. Ivanyk devoted his research: Ivanyk (2019). I. Karivets's research on this subject is also interesting (Karivets, 2019).

3 Thus, on March 28, 1939, at the twentieth meeting of PPS Philosophy Teaching Section, Kulczycki gave a report on the evaluation of the Lyceum's Philosophical Library by the Lviv Pedagogical Library entitled "Discussion of Popular Scientific Papers on Philosophical Studies from a scientific and didactic point of view". Stefan Swieżawski, 
initiative of Ivan Kuhta, the director of the Lviv Pedagogical Library, joined the publishing of book series "Philosophical Library of the Lyceum" . In this series the works of such Twardowski's students as Stepan Baley, Leopold Blaustein, Wladyslaw Witwicky, Stefan Szuman, were published (Ivanyk, 2014, p. 55). All these facts enabled Ivanyk to establish a double genetic relation between Kulczycki and the LWS: via the University of Warsaw and PPS. He proved the substantial relation between Kulczycki and the LWS on the basis of comparative analysis of his work "The Soul of Race as a Totem and the Term" (Warsaw, 1939) with the methodological and ideological ideas of the LWS. Geographical and temporal relation between Kulczycki and LWS also met the criteria of the LWS.

To prove the substantial relation between Kulczycki and LWS, Ivanyk chose the most representative work of the Ukrainian philosopher - "The Soul of Race as a Totem and the Term" (1939), because it:

- was written during LWS existence,

- is connected with Twardowski's pedagogical and theoretical activity,

- has scientific value (Ivanyk, 2014, pp. 65-66).

Yet, Kulczycki continued his scientific work after the end of the LWS functioning. Since 1940 he was an expatriate. There his teaching, research and public activities were closely connected with the Ukrainian Free University in Munich (hereinafter referred to as UFU). At the UFU the philosopher taught students the basics of philosophy and philosophical studies (1947), structural psychology (1949), introduction to philosophical anthropology $(1973)^{5}$. At these courses the scholar clearly outlined his position concerning the issues under consideration. Thus, it is important to continue the research started by Ivanyk. This will deepen the understanding of Kulczycki's philosophy and his relation to the LWS. The purpose of this

Leopold Blaustein and Roman Moncibowicz participated in the discussion of Oleksandr Kulczycki's report (Ivanyk, 2014, p. 55).

${ }^{4}$ In this series Kulczycki published his works: "Characterology of F. Künkl" (Pupil's character identification and formation) (1937), "Pedagogics of »free time«, home, school and society" (1937), "Pupil-liar (Education of honesty: its methods and importance)" (1937), "Egocentric types" (Characterology of F. Künkl in light of criticism) (1938).

5 In Ukraine, only the manuscripts of Kulczycki's lectures on the basics of philosophy and philosophical studies have been prepared for printing. The manuscripts of the lectures on the other two philosopher's courses remain little known. 
article is to analyse Kulczycki's methodological and ideological ideas of the post-war period, as well as to identify in them the traditions of the LWS on the basis of comparison with the philosophy of Twardowski in general and his students in particular.

\section{Philosophy of Kulczycki}

\section{Concept analysis}

A characteristic feature of Kulczycki's philosophical works is the precise and clear formulation of concepts. This is evidenced by a detailed analysis of such concepts as "philosophy", "worldview", "personality”, "person", "consciousness", "I" and so on.

Kulczycki defined philosophy as worldview universal knowledge. To this definition he gave the following explanations:

- philosophy is universal knowledge due to the focus on cognition in general;

- philosophy is knowledge (not science) because of the incompleteness of its efforts implemented in philosophical works;

- philosophy is knowledge through the ability to create a worldview (Kulczycki, 1995, pp. 24-28).

Clear definition of the worldview concept (Weltanschauung) needs, according to Kulczycki, clear understanding of the concept of world-picture (Weltbild). Although we know clearly only a part of the world, yet we can have and create indeed world-picture through our general worldview as the sum of «depicted» knowledge of the world. Despite the sound of the "worldview" concept, the philosopher argued that it does not mean the visual nature of the world-picture content of objects as worldview is a selection and combination of intervals of reality essential for human (Kulczycki, 1973, p. 26). Since the worldview is aimed at universal being, which encompasses not only knowledge but also values and experiences, it also includes philosophy.

The understanding of "I" is complicated, according to Kulczycki, by the polysemy and unclearness of the concept of "I". Along with "I" as a unity and bearer of consciousness, the philosopher has also distinguished the phenomenological "I", as well as the somatological-psychological "I", character-creating "I", spiritual-ideal "I", social "I", biographical-historical 
"I" and finally the real "I". The scholar defined the phenomenological "I" as the centre of mental experience that is constantly inherent in a person along with the sphere of his/her experiences. Phenomenological "I", in accordance with Kulczycki, is "pure I", on which, depending on the heterogeneous mental content, all aspects of "I" arise. The transcendental basis of all these "Is" Kulczycki called real "I": "Its hypothetical substantiality cannot be explored by psychology, but it can at least be considered metaphysically" (Kulczycki, 1949, p. 43).

\section{Psychologism}

In Kulczycki's opinion, psychology is a science especially closely related to philosophy. He defined psychology as a science of mental phenomena. According to the scholar, psychology is important for all philosophical studies, in particular for:

- ontology as psychology is about mentality - one of the most important and the closest to human form of being;

- epistemology because cognition is a mental process, and psychology, as the science of mental processes, also explores the process of cognition;

- axiology as values occur in mental processes and experiences, and the striving for truth, goodness or holiness are manifestations of the human psyche, which is the subject matter of psychology (Kulczycki, 1995, p. 49).

Kulczycki defined psychology as the methodological basis for all humanities due to their common subject - actions and products of the human psyche: "Works of art, historical events, features of great historical figures, linguistic systems become clearer if approached with psychological knowledge" (Kulczycki, 1995, p. 49).

The closest to psychology, according to Kulczycki, is philosophical anthropology. The philosopher argued that a man differs from an animal first of all and mostly by a psycho-spiritual structure, so its manifestations, namely "I", "consciousness", "person", "personality" are the basic concepts of both philosophical anthropology and anthropological psychology. If a man exists on the intersection of two realities - material and spiritual, it should be viewed from two perspectives. From the perspective of sciences, because they explain the reasons, and from the perspective of humanities, because 
they already emphasize, by their name, the close connection between philosophical anthropology and anthropological psychology as "completing the basic study of human" (Kulczycki, 1973, p. 24).

\section{Psychology}

\section{Introspectionism}

Kulczycki believed that the subject of psychology - mental phenomena does not exist beyond us, as subjects of sciences, but in ourselves, in our lives. Mental phenomena are not external, but internal. Their observation is not external, but internal, in the "soul". It is available only to someone who is experiencing them, to an agent: "Mental phenomena exist only for their bearer, for someone who thinks something, feels something, or wants something" (Kulczycki, 1949, p. 8). So, this is an introspection, "looking into ourselves": "We not only experience, but also know and cognize what we are experiencing" (Kulczycki, 1995, p. 59).

The philosopher considered introspection the main, but not the only method of psychology. In his opinion, psychology should not deny extrospection although its use in the study of psychology of behaviour or actions and products of the human spirit is based on prior familiarization with the mental life is still a method of introspection.

\section{Intentionalism}

Kulczycki did not interpret the dependence of mental phenomena on the agent as their isolation from the outward. On the contrary, he argued that mental phenomena, being given exclusively to the agent and partly dependent on him/her, are simultaneously directed at something that lies beyond them: "Feeling of love, the image of a beloved person, the desire to approach him/her are directed at something that exists beyond the phenomena (love, dreaming, desire), namely, at the beloved one" (Kulczycki, 1949, p. 8). The philosopher called intention or intentionality the orientation of mental phenomena to something: "Mental phenomena in their intentionality transcend themselves, as if transcending the boundaries of the mental" (Kulczycki, 1949, p. 8).

In this context it is worth mentioning Kulczycki's understanding of consciousness as experiencing mental contents belonging to "I". According to the philosopher, what we experience is the content of the experience, the 
bearer of the experience is our "I", and the function of the experience is the experience itself. Therefore, Kulczycki believed that the contents relation to "I" becomes the meaning of our "I", i.e. the content of consciousness. This idea goes back to Aristotle's affirmation that consciousness is "cognition of cognition" (Aristotle, 1981, 3.430a-431b). This means, in Kulczycki's opinion, that consciousness can be defined as the ability of "reflection": the function of consciousness reflects the cognizable, a cognizer and an act of cognition (Kulczycki, 1949, p. 25).

\section{The division of mental phenomena}

Kulczycki divided mental phenomena into:

- images and concepts,

- judgments,

- feelings,

- acts of will.

Only the judgments, feelings, and acts of will the philosopher considered in the ambivalent form as an expression of their opposites.

Cognition, according to Kulczycki, can occur in two different forms: in the form of perception, when using our senses we portray the world in the concrete, "sensual" images; and in the form of thinking, when we perceive from the abstract content of our consciousness "complexes of common properties" of the whole groups or the so-called "classes" of the subject of cognition by means of "concepts", or affirm or deny the existence of relations between subjects of cognition in "judgments" (Kulczycki, 1995, p. 57).

In the area of mental phenomena the philosopher distinguished two different forms: feelings as our natural "involuntary attitude and inclinations" (e.g., pleasure or displeasure) and acts of will as agreement or disagreement of our "I" to their implementation.

\section{Logic}

In thinking Kulczycki distinguished:

- the act of thinking (is the subject matter of psychology),

- the content of thinking (is the subject matter of logic),

- the subject of thinking (is the subject matter of ontology) (Kulczycki, 1995, p. 36). 
According to the scholar, logic studies the structure of a thinking content, paying particular attention to the fact that "in these contents thinking is »supra-individual «, common to all who give rise to thoughts entirely regardless of time and space" (Kulczycki, 1995, p. 36). The philosopher defined the subject of logic as identifying the correct structure (construction) of the thinking content relations. Thus, logic sets the norms of thinking.

Kulczycki considered judgment as paramount in the thinking construction system. In the judgment structure he distinguished three elements - the subject, the predicate and the conjunction. The judgment represented by two elements - the subject and the conjunction (for example, "God is") or by the predicate and the conjunction (for example, "it thunders") the philosopher referred to undeveloped forms of common judgments. This is because they can be reduced to the latter (for example, the judgment "God is" to the judgment "God exists") or to the imperative guess of an event or process (for example, the judgment "it thunders" - to the form of the expression guessing about the process of "thundering") (Kulczycki, 1995, p. 38).

\section{Ethics}

Kulczycki denied the thesis of ethical relativism that ethical values are relative, dependent on historical period and cultural environment (even on the views of certain groups of people or even individuals). The philosopher did not believe that morality obligatory for all people is impossible. In his opinion, the mental state of ethical guidance is particularly clear in the first place in the moment of universal and objective obligation to act in this way and not otherwise. In addition, it is contrary to an everyday experience: "There are probably actions that will not be approved by any group of people. What kind of people would, for instance, approve a breach of agreement or murder?" (Kulczycki, 1995, p. 132).

Kulczycki claimed that, along with variable elements in the morality of different cultures and different eras there are also common ones. He explained the heterogeneity of ethical views by the historical variability of an ethos, ethics and morality. The variability of ethical evaluation he attributed to the level of human conscience development, man's ability to judge about ethical values and to implement the moral principles in certain circumstances.

Kulczycki distinguished:

- basic ethical values (respect, honesty, love), 
- self-related values (self-faithfulness, sincerity, virtue),

- values associated with the social environment (justice, charity);

- values associated with the world and reality (courage, heroism, endurance).

All these values, according to the philosopher, comprise self-love, love to one's neighbour, and man's unity with the world and reality (Kulczycki, 1995, p. 135).

\section{Aesthetics}

Kulczycki defined aesthetics as philosophical axiological knowledge of aesthetic value and its implementation in art. The philosopher recognized aesthetic tasks in the study of essence of all that we call aesthetic in the analysis of aesthetic experience, artistic creativity and kinds of art.

The Ukrainian scholar considered essential such features of aesthetic values as:

- visual evidence,

- belonging not only to people but also to things,

- existence in a particular - aesthetic - reality (Kulczycki, 1995, p. 136).

\section{The Lviv-Warsaw School and Kulczycki's philosophy}

\section{Concept analysis}

Clearness and accuracy of a language is the characteristics of Kazimierz Twardowski's philosophical works. According to Aristotle's division of a language into poetic (colourful, extraordinary, and solemn) and usual (daily, common, and clear) (Aristotle, 1932), as well as the analytical method of Rene Descartes (1902), the LWS founder tried to purify the language of philosophy from low-quality and polysemic words. By reasoning the close interrelation between thinking and language, the philosopher denied the idea that unclear style indicates a deep philosophical content and proved that those who think clearly also should write clearly (Twardowski, 1927, p. 204).

Clearness and accuracy of a language was the prerequisite of Kulczycki's philosophism. He was convinced that the unclearness and ambiguity of concepts interfere in their understanding. This demonstrates Kulczycki's 
loyalty to the method of concept analysis by Twardowski. In addition, memoirs by Kyryl Mytrovych, Kulczycki's student, can prove this.

He put his knowledge, his beliefs in the frame of historical and current achievement of the examined subject. Therefore, his speeches or writings seemed at first glance overloaded by quotes. But soon his presentation proceeded to available clearness and methodical resolving of complicated aspects, so a listener or reader felt prepared for further searches. Again, it is worth referring to the dialogues of Socrates or Skovoroda, where there is an impression that the author's opinion is lost in the complexity of other people's thoughts. But soon it turns out that we deal with a man whose beliefs are clear, who arouses interlocutors rather than dogmatically narrowing of the idea. In the end, the interlocutor feels openly obliged to express his/ her opinion: cognize yourself (Socrates), hear yourself (Skovoroda) - that was the open end of reflection in a conversation with Professor Kulczycki (Mytrovych, 1985, p. 11).

\section{Psychologism}

In philosophy Twardowski represented the psychological trend (Twardowski, 1927d). He treated psychology as the study of mental life, in which direct knowledge is taken through introspection - an internal experience, and indirect one - its manifestations: psychophysical actions and products (Twardowski, 1965). Therefore, the philosopher believed that only psychology can provide reliable knowledge of mental life. Hence, psychology should be the basis for philosophy and humanities. Twardowski attributed some philosophical studies to one group on the basis of their common characteristics - the object existence only in internal experience or both in internal and external experience (Twardowski, 1927d, p. 27). The philosopher defined humanities as studies "whose subjects are mental products that are being considered regardless of mental actions, or also mental products that are manifestations of mental products" (Twardowski, 2013a, p. 178).

Kulczycki's definition of psychology as the basis of philosophy and humanities brings his research position close to Twardowski's philosophical tradition. This is justified by Kulczycki's focusing on specificity of the psychology subject. It is noticeable that Kulczycki emphasized the value of methodological psychologism for philosophy and humanities. As we know, Twardowski also emphasized the possibilities of methodological 
psychologism for these studies ${ }^{6}$. Definition of psychology as the basis of philosophical anthropology can be considered a contribution of the Ukrainian philosopher in the development of psychology.

\section{Psychology}

\section{Introspectionism}

Twardowski assumed that mental activity is a function of the brain since changes in the brain cause changes in the activity of a psyche. Nevertheless, the philosopher could not call mental activity a function of the brain as he did not have sufficient evidence that mental activity is solely the result of brain activity. In this regard, he cited the facts that proved the fundamental difference between mental and physical life:

- physiological phenomena have length in space, mental ones - do not;

- physiological phenomena are available to external experience, mental ones - exclusively to internal one (Twardowski, 1927d, pp. 6-9).

Kulczycki's definition of mental phenomena as internal because they do not manifest themselves from the outside, such as the growth or movement of animals, is evidence of their differentiation from physical phenomena. Hopes, dreams, desires etc. are available, according to philosopher, only to those who are experiencing it. Because of this, he called mental phenomena subjective.

The following quotations confirm the similarity of philosophers' opinions regarding the difference between mental and physical life:

Twardowski:

Anyone who wants to impartially consider the real state of affairs must regardless of their metaphysical beliefs recognize that, firstly, physiological phenomena have length in space, mental ones - do not have and, secondly, physiological phenomena are available to sensual experience, which is not true about mental ones.

(Twardowski, 1927d, p. 7).

${ }^{6}$ See, for example: Woleński (1985, p. 40). 
Kulczycki:

The internal perception of mental phenomena as a contrast to the external perception of other manifestations of life means that mental phenomena unlike the "superficial", namely the physical, chemical, organic, etc., that are spatial in nature, because they fill a certain space and appear in a certain place, have no such outlined relation to space. [...] Such a peculiar relation to space, inability to adapt spatial patterns to mental phenomena most clearly affects another feature of mental life - a way of coexistence of mental phenomena in the unity of one continuous experience.

(Kulczycki, 1995, p. 50).

The French philosopher August Comte believed that internal experience, introspection is not possible because no one can observe their own cognitive activity. A thinking person cannot be divided into two beings, one of whom would think and the other would observe thinking. Therefore, for Comte, introspection as a method of psychology is absolute fantasy. Consequently, psychology, in his opinion, should be attributed to physiology (Comte, 2000, pp. 35-37).

Twardowski, however, was convinced that the perception of one's mental states is possible for human. Otherwise, it would be unclear how he/she knows about his/her own mental activity. Thus, he did not consider internal experience as a fantasy of psychologists, but the only way to obtain direct knowledge of mental phenomena (Twardowski, 1927d, p. 13). So, psychology, in his opinion, cannot be attributed to physiology.

The impossibility of internal cognitive practice was denied, in particular, by Stepan Baley, the Ukrainian student of Kazimierz Twardowski.

Kulczycki also tried to dispel Comte's doubts about the possibility of cognition of mental phenomena through internal experience, introspection. The philosopher believed that it is possible to cognize one's own mental life due to introspection. In this case, we can get not the "astronomical" knowledge about our brain, but the knowledge of our "I".

The following quotations demonstrate the similarity of Kulczycki and the LWS considerations regarding introspection:

Baley:

After all, it is no wonder that our loved ones know and judge us sometimes better and more successful than we do. Because, when they are 
watching us, we are completely in front of them. We, when examining and judging ourselves, must be divided into two parts. There must be an observer and an observed, a judge and a defendant inside us. This self-division, while being a kind of doubling, is an art that requires effort and skill. Psychologists must master the art of looking into oneself, or introspection, as they call it, at the highest level, should train hard in it.

(Baley, 1947, p. 10).

\section{Kulczycki:}

Some philosophers (for example, August Comte) deny the value of introspection and, therefore, even the scientific nature of philosophy. [...] Opponents of introspection rely on the fact that it is impossible to internally perceive, examine any mental phenomenon, without changing it. Try to explore introspectively, for instance, anger, and you will see that since you direct your introspection, you will stop being angry. Try to think of something, and unambiguously analyse the thinking process, and answer questions about how we think. In such a situation, there seems to be a split of one's person: one who thinks and one who examines one's own thinking. The ability of introspection within the meaning of simultaneous experience and knowledge of what is experienced is doubtful. The reproaches of the opponents of introspection can be answered that introspection must be understood not as a purely simultaneous cognition of what is being experienced, but as its direct "reproduction" ("direct introspection").

(Kulczycki, 1995, p. 59).

The drawback of introspection - restriction of internal observation only to one's own psyche - in no way meant to Twardowski that its value is not the same in all areas of psychology. Even in the external exploring of mental life, such as animals, children, criminals, the psychologist constantly refers to the internal experience (Twardowski, 1927d, p. 21).

Kulczycki also admitted psychology is in need of external experience although internal experience, in his opinion, should still precede it. This proves his solidarity with Twardowski regarding introspection.

\section{Intentionalism}

Following Brentano (1874, pp. 115-116), Twardowski believed that any mental phenomenon was related to some immanent object (Twardowski, 
1965 , p. 3). It means that there are no phenomena of consciousness that do not belong to certain objects outside of consciousness and which do not correspond to any content within the consciousness. The Polish philosopher called the common feature of all these mental states when we imagine something an act of imaging. What distinguishes these acts in such a way that one of them is called the representation of something and the other is the representation of something else, is the content of representation; and what we mean when we imagine something is the object of representation.

Kulczycki's conviction about the focus of mental phenomena on something that lies beyond the psychic reveals his familiarity with Twardowski's theory of intentionality. This view is reinforced by the fact that the Ukrainian philosopher distinguished in the function of consciousness the act of cognition, along with the content of cognition and the object of cognition.

\section{The division of mental phenomena}

Twardowski divided mental phenomena into:

- representations (images and concepts),

- judgments,

- feelings,

- manifestations of will.

The Polish philosopher defined representations as the necessary condition and basis not only for judgments, but also feelings and manifestations of will. He also explained the originality of representations by the fact that judgments, feelings, and manifestations of will express themselves in a dual form, revealing a clear opposite, while images and concepts "supply material for the mind, providing its content” (Twardowski, 1927e, p. 41).

Kulczycki's consideration of cognition in the forms of perception (images) and thinking (concepts and judgments), as well as the division of mental phenomena by him into feelings and acts of will, demonstrates his simulation of classification of mental phenomena by Twardowski. Moreover, the Ukrainian philosopher recognized the originality of images and concepts in comparison with judgments, feelings, and acts of will. 


\section{Logic}

Logic, according to Twardowski, provides thinking rules, empowering them and is binding on all people. The rules of logic cannot be evaded unless one wishes to mistake (Twardowski, 1927a, pp. 348-349).

Twardowski defined judgment as the axis around which all logical researches revolve (Twardowski 2013c, pp. 31-32). The philosopher called each mental act, which contains the truth or falseness, judgment (Twardowski, 2013c, p. 38). He interpreted the truth as true judgment.

Kazimierz Twardowski contrasted the theory of conformity, which reduces the truth interpretation to the definition of judgment as a synthetic form " $S$ is $P$ " or " $S$ is not $P$ " that is, the allogenetic theory of judgment (Aristotle, Bertrand Russell) with idiogenetic theory of judgments (Rene Descartes, Franz Brentano) which reduces the truth interpretation to the definition of judgment as a form of " $S$ is" or " $S$ is not" (Twardowski, 1927b, p. 418).

According to the Ukrainian researcher of the LWS, Borys Dombrowski, the idiogenetic theory of judgment " $A$ is" stands for "the existence of the idea of object (ontology), true valuation (logic), belief in the truth and existence of $A$ (psychology), intentional attitude to the object which is its assertion or denial (axiology), definition of the $A$ object through judgment (semiotics)" (Ivanyk, 2018, p. 14).

By distinguishing content and object in thinking an act, and by defining them as a subject matter of psychology, logic and ontology, Kulczycki, similar to the LWS, emphasized that thinking is the axis around which the researches of particular philosophical studies revolve. By highlighting judgment as central in the system of thinking, the Ukrainian philosopher has clarified this axis. It is the very judgment. By paying attention to the ability of logic to exalt people over opposites and to unite them around the absolute value - the irrespective truth - Kulczycki affirmed, like most of Twardowski's students, the value of logical culture for man and society. The following quotes convince us of this:

Ajdukiewicz:

A student who does not think logically can know a lot, but will not be able to operate properly, his knowledge will lie like dead capital, from which he will not benefit. 
By spreading logical culture, we prepare the ground for a scientific worldview, and through it we pave the way for progress.

(Ajdukiewicz, 1985a, p. 142)

\section{Kulczycki:}

There is no scientific thinking without thinking laws, as there is no true understanding of humanities, legal, economic and social sciences without philosophical preparation.

(Kulczycki, 1995, p. 23)

\section{Ethics}

Twardowski disproved the arguments of the evolutionary ethics supporters that: there is absolutely no agreement on ethical principles and rules, so every nation has a different perspective on a particular issue; there are no universally recognized axioms in ethics that can serve as a basis for derivation the general principles of behaviour. In Twardowski's opinion, the absence of a general consensus on moral truths cannot at all prove that such truths do not exist; even theoretical axioms are not unconditionally recognized, but only when certain obstacles that make that recognition impossible are eliminated (Twardowski, 1927a, pp. 354-355). The philosopher believed that it is not moral truths that develop, but the person in the aspect of conscience. Man is not born with an established ethical system, but has by nature the initial germs of conscience, the development of which he/she promotes by cognition of moral truths. Moral truth is always the same (Twardowski, 1927a, p. 356). Therefore, human conscience should be developed.

Twardowski divided ethics into social and individual. Social ethics recognizes only behaviour on the human coexistence background, individual ethics - only completely isolated individual behaviour. The philosopher coordinated these two ethics as follows: social ethics also recognizes the responsibilities of a person towards himself/herself and individual ethics towards others. The difference between the two ethics that he saw was that one for one and the other for other responsibilities are basic and others are derivative (Twardowski, 2013b, pp. 407-413).

Obviously, following Twardowski, Kulczycki accepted the thesis of relativity and subjectivity of morality, without excluding the possibility of 
its generality. Therefore, he also believed that not moral truths go through different stages of development, but only humanity goes through different stages of conscience development. Kulczycki's division of moral values into individual, social and world-related can be regarded as the continuation of ethics division by Twardowski.

\section{Aesthetics}

Based on the psychological grounds of philosophy, Twardowski believed that in aesthetics there should be a move from a discussion about the nature of beauty to a detailed description and grouping of those mental actions that determine the so-called aesthetic preferences (Twardowski, 1927d, p. 24). This move was accepted and developed by Kulczycki. He associated the purpose of aesthetic with the analysis of aesthetic experiences, artistic creativity and the types of art. By defining the aesthetic values in existence in the particular reality, the Ukrainian philosopher noted that the essence of art is not the imitation of reality, but it is creating a particular reality that would reproduce real reality by its own laws. Such an idea of art was followed by one of Brentano's immediate students, the German philosopher Theodor Lipps. He expressed his belief about absolute isolation of the world of art as "a completely isolated ideal world" (Lipps, 1920, p. 38).

\section{Conclusions}

The comparative analysis of Kulczycki's methodological and ideological works of the post-war period with the philosophy of Twardowski and his students deepens the understanding of Kulczycki's philosophy and its relation to the LWS. It turns out that through his courses at university, Kulczycki transmitted to the Ukrainian students the methodological and philosophical ideas of the LWS, namely: analytical method, psychologism, introspectionism, intentionalism, epistemological and ethical absolutism. In this way, the Ukrainian philosopher promoted the LWS tradition in the Ukrainian culture of diaspora.

There is no doubt that the main source of Kulczycki's philosophy was philosophy of Twardowski. Because it was the LWS founder who defined the aim of philosophy as a search for truth and its scientific justification on 
the basis of Kant's criticism, while at the same time advocating the truth that subjectivity sees no obstacles to objectivity.

The further study of Kulczycki's philosophy also seems promising. For instance, the philosopher associated the idea of university with making scientific values on the basis of autonomy, academic freedom and communication. He believed that university should have nothing to do with politics. On the contrary, the scientific values which it produces must influence the political situation in the society (Kulczycki, 1970). Such Kulczycki's thoughts are very close to Twardowski's idea of university dignity (Twardowski, 1933). Kulczycki also criticized the Marxist-Leninist concept of man for its considering a man as the manifestation of brain material, highly organized, as the theory of reflection of atheism, as a slave of dialectical necessity and the practices of the proletariat dictatorship and the class struggle, which is the driving force of history development (Kulczycki, 1985). This is also interesting, since the LWS had also a negative attitude towards Marxism mainly because of its dogmatism ${ }^{7}$.

\section{Bibliography}

Ajdukiewicz, K. (1985a). Logika, jej zadania i potrzeby w Polsce współczesnej. In: K. Ajdukiewicz, Język i poznanie, vol. II (pp. 127-142). Warszawa: PWN.

Ajdukiewicz, K. (1985b). O potrzebie usługowego kursu logiki w programach studiów uniwersyteckich. In: K. Ajdukiewicz, Język i poznanie, vol. II (pp. 192-205). Warszawa: PWN.

Aristotle (1932). Poetics. Trans. W.H. Fyfe. In: Aristotle, Aristotle in 23 Volumes, Vol. 23. London: William Heinemann Ltd. Retrieved from: http://www.perseus.tufts.edu/hopper/text?doc=urn:cts: greekLit:tlg0086.tlg034.perseus-eng1 (20.03.2020).

Aristotle (1981). On the Soul. Trans. J.A. Smith. Retrieved from: http://classics.mit. edu//Aristotle/soul.html (20.03.2020).

Baley, S. (1947). Drogi samopoznania. Kraków: Wiedza. Zawód. Kultura.

Brentano, F. (1874). Psychologie vom empirischen Standpunkte. Bd I. Leipzig: Verlag von Duncker \& Humblot's. Retrieved from: https://archive.org/stream/ psychologievome 02brengoog\#page/n4/ mode/2up (20.03.2020).

${ }^{7}$ See, for example: Brożek (2010), p. 175. 
Brożek, A. (2010). Kazimierz Twardowski w Wiedniu. Warszawa: Semper.

Comte, A. (2000). The Positive Philosophy. Trans. H. Martineau. Kitchener: Batoche Books.

Descartes, R. (1902). Discours de la méthode \& Essais. Paris: Léopold Cerf, Imprimeur-Éditeur.

Ivanyk, S. (2014). Filozofowie ukraińscy w Szkole Lwowsko-Warszawskiej. Warszawa: Semper.

Ivanyk, S. (red.) (2018). Teoria sądów w Lwowskiej Szkole Filozoficznej. Antologia. Kamieniec Podolski: Wydawnictwo Lwowskiego Towarzystwa Filozoficznego im. Kazimierza Twardowskiego.

Ivanyk, S. (2019). Franz Brentano's Influence on Ukrainian Philosophy: A Methodological Introduction to Research. East/West: Journal of Ukrainian Studies, 6, 125-146.

Karivets, I. (2019). F. Brentano and K. Twardowski: Some Traces of Their Influence on the Contemporary Ukrainian Scholars. Problemos, 96, 96-106. DOI: https://doi.org/10.15388/Problemos.96.8.

Kulczycki, O. (1985a). A Man According to H. Skovoroda's Phylosophy Antithesis of the Marxist-Leninist Concept of a Man. In: O. Kulczycki, Ukrainian Personalism. Philosophical and Ethnopsychological Synthesis (pp. 37-48). Munich-Paris: The Ukrainian Free University [in Ukrainian].

Kulczycki, A. (1937a). Charakterologia F. Künkla. (Kształtowanie się charakteru wychowanka i jego kształcenie). Lwów: Nakładem Lwowskiej Biblioteczki Pedagogicznej.

Kulczycki, A. (1937b). Pedagogika “wolnego czasu” a dom, szkoła i społeczeństwo. Lwów: Nakładem Lwowskiej Biblioteczki Pedagogicznej.

Kulczycki, A. (1937c). Uczeń kłamca. (Wychowanie do prawdomówności-jego sposoby oraz doniosłość). Lwów: Nakładem Lwowskiej Biblioteczki Pedagogicznej.

Kulczycki, A. (1938). Typy egocentryczne. (Charakterologia F. Künkla w świetle krytyki). Lwów: Nakładem Lwowskiej Biblioteczki Pedagogicznej.

Kulczycki, O. (1949). Essay on Structural Psychology. Munich: The Ukrainian Free University [in Ukrainian].

Kulczycki, O. (1970). Overcoming Boundary Situation. The Ukrainian Free University - Its Originality. Nowadays, 1, 88-94 [in Ukrainian]. 
Kulczycki, O. (1973). Introduction to Philosophical Anthropology. Munich: The Ukrainian Free University [in Ukrainian].

Kulczycki, O. (1995). Fundamentals of Philosophy and Philosophical Studies. Munich-Lviv: The Ukrainian Free University [in Ukrainian].

Lipps, T. (1920). Ästhetik Psychologie des Schönen und der Kunst. Zweiter Teil: Die ästhetische Betrachtung und die bildende Kunst. Leipzig: Verlag von Leopold Voss.

Mytrovych, K. (1985). Professor Kulczycki among Us. In: O. Kulczycki, Ukrainian Personalism. Philosophical and Ethnopsychological Synthesis (pp. 5-14). Munich-Paris: The Ukrainian Free University [in Ukrainian].

Twardowski, K. (1927a). Etyka wobec teoryi ewolucyi In: K. Twardowski, Rozprawy i artykuły filozoficzne (pp. 343-356). Lwów: Księgarnia SA “Książnica-Atlas” T.N.S.W.

Twardowski, K. (1927b). O idio- i allogenetycznych teoriach sądów. In: K. Twardowski, Rozprawy i artykuły filozoficzne (pp. 418-420). Lwów: Księgarnia SA “Książnica-Atlas” T.N.S.W.

Twardowski, K. (1927c). O jasnym i niejasnym stylu filozoficznym. In: K. Twardowski, Rozprawy i artykuly filozoficzne (pp. 203-205). Lwów: Księgarnia SA "Książnica-Atlas" T.N.S.W.

Twardowski, K. (1927d). Psychologia wobec fizjologii i filozofii. In: K. Twardowski, Rozprawy i artykuty filozoficzne (pp. 3-32). Lwów: Księgarnia SA "Książnica-Atlas" T.N.S.W.

Twardowski, K. (1927e). W sprawie klasyfikacyi zjawisk psychicznych. In: K. Twardowski, Rozprawy i artykuły filozoficzne (pp. 33-42). Lwów: Księgarnia SA “Książnica-Atlas" T.N.S.W.

Twardowski, K. (1933). O dostojeństwie Uniwersytetu. Poznań: Uniwersytet Poznański.

Twardowski, K. (1965). O psychologii, jej przedmiocie, zadaniach, metodzie, stosunku do innych nauk i jej rozwoju. In: K. Twardowski, Wybrane pisma filozoficzne (pp. 241-291). Warszawa: Państwowe Wydawnictwo Naukowe.

Twardowski, K. (2013a). Nauki humanistyczne a psychologia. In: K. Twardowski, Myśl, mowa i czyn. Part I (pp. 174-185). Kraków: Copernicus Center Press.

Twardowski, K. (2013b). O zadaniach etyki naukowej. In: K. Twardowski, Myśl, mowa i czyn. Part I (pp. 402-436). Kraków: Copernicus Center Press. 
Twardowski, K. (2013c). Teoria sądów. In: K. Twardowski, Myśl, mowa i czyn. Part I (pp. 28-53). Kraków: Copernicus Center Press.

Woleński, J. (1985). Filozoficzna szkoła lwowsko-warszawska. Warszawa: PWN.

Yerzhabkova, B. (1981). Bibliography of Scientific Works by Oleksandr Kulczycki, 1895-1980. Liberation Path: Socio-Political and Academic-Literary Monthly Magazine, 2 (395), 220-229 [in Ukrainian].

Zamecki, S. (1977). Koncepcja nauki w Szkole Lwowsko-Warszawskiej. Wrocław: Zakład Narodowy im. Ossolińskich.

\section{OLEKSANDR KULCZYCKI'S PHILOSOPHY AND THE LVIV-WARSAW SCHOOL}

\section{Summary}

The Lviv-Warsaw School should be treated, due to the research made by Stepan Ivanyk, the Ukrainian philosopher, as a multicultural intellectual formation with its Ukrainian branch as an integral part. In particular, Stepan Ivanyk has proven that Oleksandr Kulczycki, the Ukrainian philosopher was Kazimierz Twardowski's student. To prove the substantial relation between Kulczycki and the Lviv-Warsaw School, Ivanyk has chosen "The Soul of Race as a Totem and the Term" by Kulczycki as the basis because it met the time, genetic, and theoretical criteria.

However, Kulczycki continued his scientific work after the end of the LvivWarsaw School functioning (according to Jan Wolenski). Since 1940, his teaching, research and public activities were closely connected with the Ukrainian Free University in Munich. Therefore, it is important to continue the research started by Ivanyk, as it will deepen the understanding of Kulczycki's philosophy and his relation to the Lviv-Warsaw School. 